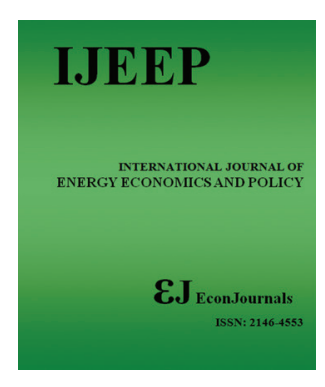

\title{
International Journal of Energy Economics and Policy
}

ISSN: $2146-4553$

available at http: www.econjournals.com

International Journal of Energy Economics and Policy, 2020, 10(4), 229-233.

\section{Household Electricity Demand in South Sulawesi, Indonesia}

\author{
Buyung Romadhoni ${ }^{1 *}$, Akhmad ${ }^{2}$ \\ Faculty of Economics and Business, University of Muhammadiyah Makassar, Indonesia. *Email: buyung@unismuh.ac.id
}

Received: 23 January 2020

Accepted: 29 April 2020

DOI: https://doi.org/10.32479/ijeep.9280

\begin{abstract}
The current demand of electrical energy is a necessity in performing human activities. The demand is increasing every year with the increase in community welfare and electronic equipment finding. The research aims to know factors influencing household electricity demand. The research uses cross-section data of household electricity consumers. Data collected are processed and analyzed using multiple regression analysis double log method. The research results indicate that factors influencing the electricity demand for household group with low electric power installed include: the amount of power of the electronic appliances used and household income, whereas for household group with medium electric power was positively and significantly influenced by: The amount of power of the electronic appliances used, household income, number of family member and number of room. For group with high electric power it was positively and significantly influenced by the amount of power of the electronic equipments used, number of room, number of family member and building area. Hence, to minimize the electrical energy usage, it is required the use of power saving electronic appliances.
\end{abstract}

Keywords: Electrical Energy, Demand, Household

JEL Classifications: C13, D10, Q41

\section{INTRODUCTION}

The current electricity demand is very crucial in performing daily activities. It increases every year with the increase of community income, economic growth, and population (Sekretaris Dewan Energi Nasional, 2016). In Indonesia, it is the duty of the government to guarantee the electrical energy availability for industrial, commercial as well as household demand (Kementerian Energi dan Sumbedaya Mineral, 2016).

Electricity is an important energy source in household life. So important is electrical energy that human could not be separated from its availability for production, trade or household life activities (Mulyani and Hartono, 2018). In the households, electrical energy is not only required as lighting devices but also for the use of home electronic appliances (Saepudin, 2018).

The increase in electricity demand and fuel oil, in general, according to (Bachtiar, 2013), (Akhmad and Amir, 2018),
(Kuswara, 1997) is caused by: (1) the growth in gross domestic product along with an increase in economic activities, (2) the increase in the use of electronic goods and (3) the change in generators due to low economic scale as well as the growth of new generators due to distribution and transmission. In addition, population growth with the growth of household number requires attention in terms of future electric power procurement.

The increase in energy demand in Indonesia must offset with energy availability, including electrical energy (Latif, 2016), (Akhmad et al., 2019). Therefore, due to the importance of electrical energy for community's daily life, the government needs to take significant action to fulfill electrical energy availability affordable for all societies.

PT. Perusahaan Listrik Negara (PLN) as a sole right holder for electrical energy provision for communities (monopoly) divides electricity consumers into various groups. According to economic activities, the consumers are divided into four groups, namely: 
(1) business, (2) industry, (3) public or government and (4) household (Perusahaan Listrik Negara, 2017). The household group at present is the largest electric consumption in the state. The business group consists of: Trade, financial service, restaurants, entertainment service, lodging service and social services. The industrial group includes textile, metal, food, machinery, automotive and other industries. The public group comprises all government offices, central as well as regional governments. The electricity demand for the four groups is increasing every year.

The increase in community income, population and electrification program from the government encourages increased electricity demand in the communities both for business and household necessities. The need of community for electronic appliances such as TV, AC, refrigerators, and other increases with community income (Holtedahl and Joutz, 2004), (Lubis and Nababan, 2011). The electricity demand also increases along with the rapid development of housing and increasing population.

Therefore, the PT PLN persero is demanded to continue increasing its electricity supply. It must be conducted well and planned since it would bring crisis on national electricity condition in the future if there is no additional new power plant capacity by the PT PLN. The reason is related to the growth in electricity demand for the last 5 years that continues to increase by $7-11 \%$ per year despite the economic condition that has not fully recovered (Sekretaris Dewan Energi Nasional, 2016). On the other hand, PT PLN Persero is only capable of fulfilling the growth in demand of $5 \%$ per year (Samudro, 2016). Thus, the demand is greater than the supply, especially electricity availability outside the Java and Bali Islands.

South Sulawesi Province has 20 regencies and three cities and population of $8,771,970$ people with number of household of 2,014,073 head of families in 2018 (Badan Pusat Statistik, 2019). As part of national electricity system, South Sulawesi Province is one of areas in Indonesia where almost all of its regencies and cities have been equipped with electricity facilities. The growth of average electricity demand in the area for the last 5 years is $9.1 \%$ per year. In 2019, the amount of installed capacity is $2,841,564,900$ VA that comprises $268,727,400$ for 450 VA group, $164,762,000 \mathrm{VA}$ for $900 \mathrm{VA}$ S/D 2200 VA group and 175,326,700 for above 3500 VA group. (PT. PLN Wilayah Sulawesi Selatan, 2019). Therefore, PT. PLN as a single electricity provider for household is required to adjust the available power to community demand for electricity. Hence, the research aims to know factors influencing household electricity demand in South Sulawesi Province.

\section{LITERATURE REVIEW}

\subsection{Willingness to Pay (WTP) Concept}

In general, household demand model, such as electrical energy, always connects to demand utility of electrical energy (Guertin et al., 2003). The fact, however, indicates that price variable or electricity tariffs in Indonesia is set by the government, in this case, PT PLN (persero) as a company that provides electrical energy for the community. As consequence, we cannot use market price as a pricing base. Thus, we could use willingness to pay concept as electricity price variable (Varian, 1992), (Nicholson, 2005).
The willingness to pay approach aims to obtain the willingness of consumers to pay for the electricity price set.

According to (Zhao and Kling, 2004) willingness to pay is the willingness of consumers to pay a number of goods and services at a certain time or the willingness of consumers to pay a certain amount for goods purchased at a certain time. Therefore, electricity rates in Indonesia are unilaterally set by the government or state electricity company (PLN). The reason is that electricity is a public good and it is related to the needs of many people's lives. In addition, it must be controlled by the state and it requires subsidy to achieve social justice. Based on the consideration, price or tariffs in the current research proxies by willingness to pay (WTP) with contingent valuation (CV) method. It aims to find out the willingness of households to pay the electricity tariffs charged. The CV model used to obtain WTP is a closed-ended referendum format model.

The determination of electricity tariff with WTP approach is possible with the following considerations: (1) it allows consumers to reveal the real price of a good and service; (2) the electricity energy tariffs in Indonesia is an increasing block-rate pricing so as each group has different tariff charged (Pattanayak et al., 2006). Thus, marginal price or average price is appropriate for the model. It is, however, only suitable if we use time series data. The research, on the other hand, used cross-section data of household electrical energy consumers (Rozan et al., 2004).

\subsection{Electricity Demand}

Electricity energy price'/tariff policy in Indonesia is set by PT PLN (Persero) as the only electricity energy provider company (monopoly). The determination of electricity tariffs in Indonesia is in form of increasing block-rate pricing. Thus, price is set differently for each group of usage level stratum. The tariff system indicates that electricity tariffs in the same group has no price variation and consumers only acts as price receiver (Kementerian Energi dan Sumbedaya Mineral, 2016). Therefore, this research electricity tariff is not included as an estimation variable.

The electricity demand is generally influenced by several factors. The electricity usage for each consumer group is basically different. The difference depends on: (1) type of object that uses the electrical energy and (2) the usage period (Philipson and Willis, 1999), (Surbakti and Kodoatie, 2013), (Musibau et al., 2019). The electricity demand level based on customer group, time and power is influenced by: (1) time; (2) weather and (3) the occurrence of important events (Kadir, 2000), (Guiliany et al., 2020). Further, (Nagurney and Arneaux, 1991), (Comfort et al., 2018), state that the electricity demand is influenced by: Usage time, economic condition, weather condition, AC usage, number of owned electronic appliances, demographic condition, television usage and other electronic appliances usage.

The household electricity demand is influenced by: Number of electronic appliances or electrical appliances used, household income, applicable electricity tariffs, demographic variables, location and education level of head of family (Matsukawa, 
Table 1: Estimation results of household electricity demand model in south sulawesi province

\begin{tabular}{|c|c|c|c|c|c|}
\hline Variables & Estimation parameter & t. value & $\operatorname{Pr}>t$ & $\mathbf{R}$ & $\mathbf{F}$ \\
\hline \multicolumn{6}{|l|}{ R-1/TR 450 VA } \\
\hline Intercept & 30.051 & $<0.0001$ & & 0.8727 & 87.27 \\
\hline $\mathrm{X} 1=$ Amount of electronic appliance power used & 0.2966 & 3.3210 & 0.0470 & & \\
\hline $\mathrm{X} 2=$ Household income & 0.1012 & 5.1341 & 0.0082 & & \\
\hline X3 =Number of family member & 0.1856 & 1.1031 & 0.1030 & & \\
\hline $\mathrm{X} 4=$ Number of room in a household & 0.2624 & 0.9075 & 0.2782 & & \\
\hline $\mathrm{X} 5=$ Building area & 0.0348 & 0.1431 & -0.5180 & & \\
\hline X6 $6=$ Education level of head of family & -0.8025 & 0.0173 & 0.0497 & & \\
\hline \multicolumn{6}{|l|}{ R1/TR900-R1 $2200 \mathrm{VA}$} \\
\hline Intercept & 75.23 & $<0.0001$ & - & 0.9127 & 139.02 \\
\hline $\mathrm{X} 1=$ Amount of electronic appliance power used & 0.6966 & 6.2401 & 0.0070 & & \\
\hline $\mathrm{X} 2=$ Household income & 0.0514 & 3.0532 & 0.0491 & & \\
\hline $\mathrm{X} 3=$ Number of family member & 0.1851 & 3.1031 & 0.0430 & & \\
\hline $\mathrm{X} 4=$ Number of room in a household & 0.0610 & 3.8061 & 0.0251 & & \\
\hline $\mathrm{X} 5=$ Building area & -0.0213 & 0.0431 & -0.3180 & & \\
\hline $\mathrm{X} 6=$ Education level of head of family & 0.0256 & 0.1132 & 0.8697 & & \\
\hline \multicolumn{6}{|l|}{ R2 and R3 2201 VA and above } \\
\hline Intercept & 102.03 & $<0.0001$ & - & 0.9003 & 99.71 \\
\hline $\mathrm{X} 1=$ Amount of electronic appliance power used & 0.4532 & 9.1301 & 0.0007 & & \\
\hline X2=Household income & 0.0222 & 0.4241 & 0.1452 & & \\
\hline X3=Number of family member & 0.5651 & 6.0104 & 0.0065 & & \\
\hline $\mathrm{X} 4=$ Number of room in a household & 0.2410 & 5.7702 & 0.0082 & & \\
\hline X5=Building area & 0.4813 & 0.0431 & 0.0180 & & \\
\hline X6=Education level of head of family & -0.0452 & 3.4173 & -0.2442 & & \\
\hline
\end{tabular}

2004); (Humbatova et al, 2020); (Nando, 2018); (Moranco et al., 2005).

Studies on household electricity demand in Indonesia are still limited. For example, studies by (Bachtiar, 2013), at guntarano village tanantovea sub-district donggala regency, (Santosa et al., 2019), at prisma asri housing complex in tegal regency central java and (Rahim et al., 2018) in South East Sulawesi that used time series data in 1985-2016. Those studies used variables of household income, electricity tariffs, and number of household member and room. They also estimated electricity demand and requirement as a whole, whereas in Indonesia, consumers are divided into several strata according to the installed capacity. Household in Indonesia is categorized into six groups, namely: R1/TR 450 VA; R1/TR 900 VA; R1/TR 1300VA; RI/TR 2200VA; $\mathrm{R} 2 / \mathrm{TR}$ 2201-6600VA, and R3/TR > $6600 \mathrm{VA}$. In the current research, therefore, we divided household consumers into three groups, namely: (1) R1/TR450VA, (2) R1/TR900VA to 2200VA, and (3) R2 and R2 TR >2201VA. The grouping was based on consideration that Group 1 represented low income consumer group, group 2 represented middle class consumers and Group 3 represented upper class consumers.

\section{RESEARCH METHOD}

The research population included all households that subscribed to electricity to PT. PLN (Persero) South Sulawesi Province region. The population spread in 23 regencies and cities. Sampling was conducted based on cluster random sampling technique. In this technique, households were divided into three groups, namely: (1) R-1/TR 450VA, low electrical energy user group (subsidized) (2) R1/TR900-R1 2200VA, medium electricity user group, and (3) R2/R3 2201 above. 100 samples were chosen for each group. Next, sampling was conducted randomly in each household group from the selected regencies and cities.

The research used cross-section data from household electricity consumers in South Sulawesi Province. The data collected consisted of: (1) average household electricity consumption for 6 months from January to June 2019, (2) amount of capacity for each electronic appliances used, (3) average household income, (4) number of room, (5) building area, (6) number of family member and (7) education level of head of family. The secondary data used included demographic data and electricity obtained from Bureau of Statistics of South Sulawesi Province and PT PLN (Persero) of South Sulawesi Province.

\subsection{Analysis Method}

Multiple linear regression analysis was used to estimate home electricity demand in South Sulawesi Province by using double log method or natural logarithm ( $\mathrm{Ln})$. The developed natural logarithm is presented as follows.

$$
\begin{aligned}
& \operatorname{LnY}=a+b_{1} \operatorname{LnX} X_{1}+b_{2} \operatorname{LnX}_{2}+b_{3} \operatorname{LnX}_{3}+ \\
& b_{4} \operatorname{LnX}_{4}+b_{5} \operatorname{LnX}_{5}+b_{6} \operatorname{LnX}_{6}+\mathrm{e}
\end{aligned}
$$

where:

$\mathrm{Y}=$ Household electricity demand

$\mathrm{X} 1=$ Amount of electronic appliance power used

$\mathrm{X} 2=$ Household income

$\mathrm{X} 3=$ Number of family member

$\mathrm{X} 4=$ Number of room in a household

$\mathrm{X} 5=$ Building area

$\mathrm{X} 6=$ Education level of head of family $\mathrm{e}=$ Error term

$$
\mathrm{b}_{1}, \mathrm{~b}_{2}, \mathrm{~b}_{3}, \mathrm{~b}_{4}, \mathrm{~b}_{5} \text {, and } \mathrm{b}_{6}=\text { coefficient/slope }
$$


where:

$\mathrm{b}_{1}, \mathrm{~b}_{2}, \mathrm{~b}_{3}, \mathrm{~b}_{4}, \mathrm{~b}_{5}>0$ and $\mathrm{b}_{6}<0$

Model estimation was conducted using ordinary least square (OLS) technique. To ensure that the regression coefficient is the best linear unbiased estimator (BLUE), autocorrelation, heteroscedasticity and multicolinearity tests were conducted.

\section{RESEARCH RESULTS}

The results of identification on home appliances that used electrical energy indicated that for household group of R-1/TR 450VA, a subsidized electricity user group, the electricity usage was generally intended for: Lighting, refrigerators, water machine, television, fan, and kitchen appliances that had low electrical power. The electricity bill paid by the group was Rp 50,000-Rp 120,000/month, on average.

In the second group, which was R1/TR900-R1 2200VA of middle class electricity users, the electricity usage was, generally, intended for: lighting, refrigerators, water machine, 2-4 televisions, 1-4 ACs and kitchen appliances and other electronic appliances. The electricity bill paid by the group was Rp 150,000-Rp 3,000,000/ month, on average. The third group, which was R2 and R3 2201 VA and above, the electricity usage consisted of lighting, refrigerators, water machine, 3 or more television units, AC of more than 3 units, AC central and other equipment in the kitchen or others. Their electricity bill per month was above Rp 3,000,000, on average.

\subsection{Model Estimation Results}

The result of household electricity demand model estimation in South Sulawesi Province was grouped into three, namely: (1) R-1/ TR 450VA, subsidized electricity user group (2) R1/TR900-R1 2200VA, middle power electricity user group and (3) R2/R3 2201 or above, large electric power groups.

The model estimation results indicated that the amount of electronic appliance power used had a positive and significant influence on household electricity demand for every stratum in South Sulawesi Province. This finding was in line with (Nababan, 2015) finding that studied on the characteristics of simple-household electricity demand. The model estimation result of R1 450VA group obtained 0.2966 indicating that for every $1 \%$ increase in electronic appliances resulted in an increase in electricity demand of $0.296 \%$. The model estimation result of R1900 VA -2200VA group obtained 0.6966 indicating that for every $1 \%$ increase in electronic appliances resulted in an increase in electricity demand of $0.6966 \%$. Further, the model estimation result of R2 and R3 2201 VA and above group obtained 0.4532 indicating that for every $1 \%$ increase in electronic appliances resulted in an increase in electricity demand of $0.4532 \%$.

The model estimation result on household income found that household income had a positive and significant influence for lower group, which was R1 450 VA and middle group of R1 900 VA-2200 VA. The R2 and R3 2201 VA and above group, however, the influence was positive yet insignificant. If we focused on the coefficients of estimation result of household income on electricity demand, the numbers were relatively small, which were 0.1012 for R1 $450 \mathrm{VA}, 0.0514$ for R1 $900 \mathrm{VA}-220 \mathrm{VA}$ and 0.0222 for R2 and R3 2201 VA and above. Therefore, we could conclude that the higher the installed capacity stratum, the smaller the portion of household income used for electricity consumption.

The number of family member variable had a positive and significant influence for R1 900VA-2200 VA and R2/R3 2201 VA and above groups. The R1 450 VA group, however, the influence was only positive. It indicated that for every additional household member would increase the use of household electricity usage. The finding was in line with finding from (Filippini and Pachauri, 2004), (Peterson, 2002) that number of children had a significant influence on electricity consumption.

The model estimation result also obtained that number of room variable had a positive and significant influence for R1 $900 \mathrm{VA}$ - 2200 VA and R1/R2 2201 VA and above groups, whereas for R1 450 group the influence on household electricity demand was positive yet insignificant. It can be explained that for households with high electricity power above 2201 VA it was found that more than $70 \%$ of the rooms were equipped with $\mathrm{AC}$ and TV, whereas for middle group of R1 $900 \mathrm{VA}-2200 \mathrm{VA}$ it was found that $<50 \%$ of their rooms were equipped with $\mathrm{AC}$ and TV. The research results were also in line with (Assagaf, 2010) who studied middle class household electricity demand.

The model estimation result on building area variable found that the variable had a positive and significant influence for household group with high electricity capacity installed. The influence, however, was insignificant for low and medium electricity user household groups. The finding was in line with (Jung, 1993) who studied household electricity in South Korea.

The estimation results also suggested that variable of education level of head of household for all household groups, lower, middle and upper, had no significant influence on household electricity usage. The finding was in line with (Jung, 1993) finding in South Korea.

\section{CONCLUSION AND RECOMMENDATIONS}

The research results indicated that for electricity household customers with low installed capacity it was found that the amount of electronic appliance power used and household income had a positive and significant influence on electricity usage. Whereas, for customers with medium electrical energy installed capacity it was found that number of family member and number of room had a positive and significant influence on household electricity usage. Moreover, household with high installed capacity it was found that variables of amount of electronic appliance power, number of family member, number of room and building area had a positive and significant influence on household electricity usage. The research results also indicated that the variable of education level of head of household had no significant influence on household electricity usage for lower, medium as well as high installed capacity.

Following recommendations are suggested:

1. Regarding household electricity usage saving, it is necessity to use electronic appliances with low electric power. Therefore, 
it is expected that in the future, electronic appliances with lower electric power could be found

2. In order to expand the research scope, it is expected that in the future, researches conducted are not merely from demand side but also from supply side and the consumer groups are not limited to household group but also covers consumers, social, business, industry and public.

\section{REFERENCES}

Akhmad, A., Amir, A. (2018), Study of fuel oil supply and consumption in Indonesia. International Journal of Energy Economics and Policy, 8(4), 13-20.

Akhmad, A., Romadhoni, B., Karim, K., Tajibu, M.J., Syukur, M. (2019), The impact of fuel oil price fluctuations on Indonesia's macro economic condition. International Journal of Energy Economics and Policy, 9(2), 277-282.

Assagaf, A. (2010), Analisis faktor-faktor yang mempengaruhi permintaan tenaga listrik konsumen rumah tangga sedang PT. Perusahaan listrik negara (persero). Jurnal Ilmu Ekonomi dan Manajemen, 6(3), 23-67.

Bachtiar, M. (2013), Analisis faktor-faktor yang mempengaruhi permintaan konsumen terhadap listrik pada rumah tangga di desa guntarano kecamatan tanantovea kabupaten donggala. E-Jurnal Katalogis, 1(3), 1-14.

Badan Pusat Statistik. (2019), Sulawesi Selatan dalam Angka. Makassaar: Badan Pusat Statistik Provinsi Sulawesi Selatan.

Comfort, E., Ojamaliya, A., Victoria, O., Abigail, G., Oluwapelumi, A. (2018), Dynamic impact of energy consumption on the growth of Nigeria economy (1986-2016): Evidence from symmetrical autoregressive distributed lag model. International Journal of Energy Economics and Policy, 8(2), 188-195.

Filippini, M., Pachauri, S. (2004), Elasticities of electricity demand in Urban Indian households. Energy Policy, 32(3), 420-429.

Guertin, C., Kumbhakar, S.C., Duraiappah, A.K. (2003), Determining Demand for Energy Services: Investigating Income-driven Behaviours. Canada: International Institute for Sustainable Development.

Guiliany, J.G., Franco, E.D., Toscano, A.D.R., Hernández, J.D.D., Palma, H.G.H. (2020), Multiple linear regression model applied to the projection of electricity demand in Colombia. International Journal of Energy Economics and Policy, 10(1), 419-422.

Holtedahl, P., Joutz, F.L. (2004), Residential electricity demand in Taiwan. Energy Economics, 26, 201-224.

Humbatova, S.I., Ahmadov, F.S., Seyfullayev, I.Z., Hajiyev, N.G. (2020), The relationship between electricity consumption and economic growth: Evidence from Azerbaijan. International Journal of Energy Economics and Policy, 10(1), 436-455.

Jung, T.Y. (1993), Ordered logit model for residential electricity demand in Korea. Energy Economics, 25(1), 205-209.

Kadir, A. (2000), Distribusi dan Utilisasi Tenaga Listrik. Jakarta: UI Press.

Kementerian Energi dan Sumbedaya Mineral. (2016), Manajemen Rantai Penyediaan dan Pemanfaatan Energi Nasional. Jakarta: Kementerian Energi dan Sumber Daya Mineral.

Kuswara, U.D. (1997), Kajian ringkas tentang energi listrik di Indonesia: Antisipasi kebutuhan dan mismanajemen dalam pengelolaan. Kelola, Gadjah Mada University Business Review, 15(6), 105-114.

Latif, A. (2016), Dinamika sektor kelistrikan di Indonesia: Kebutuhan dan ferforma penyediaan. Jurnal Ekonomi dan Pembangunan, 24(1), 29-41.

Lubis, E.H., Nababan, T.S. (2011), Analisis faktor-faktor yang mempengaruhi permintaan konsumen listrik pada rumah tangga sederhana. Jurnal Ekonomi dan Bisnis, 2(2), 30-36.

Matsukawa, I. (2004), The effects of information on residential demand for electricity. The Energy Journal, 25(1), 1-17.
Moranco, A.B., Fuertos-Eugenio, A.M., Salazar, S.D.S. (2005), A comparison of empirical models used to infer the willingness to pay in contingent valuation. Empirical Economics, 30(1), 235-244.

Mulyani, D., Hartono, D. (2018), Pengaruh efisiensi energi listrik pada sektor industri dan komersial terhadap permintaan listrik di Indonesia. Jurnal Metode Kuantitatif Terapan, 11, 1-17.

Musibau, H.O., Mahmood, S., Ismail, S., Haruna, M.A., Khan, M.U. (2019), Electricity availability, human capital investment and sustainable economic growth causality in Sub Sahara Africa: Revisited evidences. International Journal of Energy Economics and Policy, 9(6), 222-233.

Nababan, S.T. (2015), Household characteristics that influence simple household demand on electricity. Jurnal Ekonomi Pembangunan, 16(1), 61-74.

Nagurney, F., Arceneaux, D. (1991), A model for predicting electrical peak demand. Journal of Business Forecasting, 10(2), 5-7.

Nando, C. (2018), Is there a relationship between information and communication technologies infrastructure, electricity consumption and total factor productivity? Evidence from a panel of African countries. International Journal of Energy Economics and Policy, 8(4), 207-218.

Nicholson, W. (2005), Microeconomic Theory: Basic Principles and Extensions. New York: Thompson South-Western.

Pattanayak, S., Van den Berg, C., Jui-Chen, Y., Van Houtven, G. (2006), The Use of Willingness to Pay; Experiments: Estimating Demend for Piped Water Connections in Sri Lanka: World Bank Research Working Paper, World Bank. p1-47.

Perusahaan Listrik Negara. (2017), Inspiring Journey of Transformation; Laporan Tahunan 2017. Jakarta: PT Perusahaan Listrik Negara, Persero.

Peterson, S.L. (2002), Micro econometric modelling of household energy: Testing for dependence between demand for electricity and natural gas. The Energy Journal, 23(4), 67-84.

Philipson, L., Willis, H.L. (1999), Understanding Electric Utilities and De-regulation. New York: Marcel Decker Inc.

PT. PLN Wilayah Sulawesi Selatan. (2019), Laporan Tahunan. Makassar: PT. PLN Wilayah Sulawesi Selatan.

Rahim, M., Adam, P., Ode Suriadi, L., Saenong, Z., Atmodjo, E., Rumbia, W.A., Tamburaka, I.P. (2018), Causal relationship between electric consumption and economic growth in South East Sulawesi. International Journal of Energy Economics and Policy, 8(6), 29-34.

Rozan, A., Stenger, A., Willinger, M. (2004), Willingness to pay for food safety; an experimental investigation of quality certification on bidding behaviour. European Review of Agricultural Economics, 30(4), 409-425.

Saepudin, T. (2018), Development of electricity program, electrificaty ratio with human development index in west java province, Indonesia. International Journal of Energy Economics and Policy, 8(1), 227-230.

Samudro, G. (2016), Konservasi energi berbasis renewable energy technology dengan pemanfaatan teknologi microbial. Jurnal Presipitasi, 13(2), 57-65.

Santosa, I., Susetyo, B., Ponoharjo. (2019), The intensity of energy consumption by electrical household devices in the pisma asri housing complex, Indonesia. International Journal of Energy Economics and Policy, 9(3), 154-159.

Sekretaris Dewan Energi Nasional. (2016), Indonesia Energy Outlook 2016. Jakarta: Sekretaris Jenderal Dewan Energi Nasional.

Surbakti, W.H., Kodoatie, J.M. (2013), Analisis permintaan riil energi listrik di jawa tengan dan di Yogyakarta. Diponegoro Journal of IESP, 2(1), 1-9.

Varian, H.R. (1992), Microeconomic Analysis. New York: W.W. Norton \& Company.

Zhao, J., Kling, C.L. (2004), Willingness to pay, compensating variation, and the cost of commitment. Economic Inquiry, 42(3), 503-517. 